\title{
PERANCANGAN MAN HOUR INTEGRATED CONTROL APPLICATION PADA PERUSAHAAN BARBASIS PROJECT
}

\author{
Rahayu Ary Yuniarti \\ Information Systems Department, School of Information Systems, Binus University \\ Jl. K.H. Syahdan No. 9, Palmerah, Jakarta Barat 11480 \\ ary.yuniarti@binus.ac.id
}

\begin{abstract}
ABSTRAK
The purpose of the study is to analyze and design an integrated application for managing man hour called Manhour Integrated Control Application (MICA) for a project-based company. Users can easily monitor the progress of man hour's usage using this application which can be accessed from different project sites. The methodology used in the study are (1) analysis towards the business process followed by identification of user requirement by interview with user, document analysis and literature study; and (2) design for database and user interface. The result expected from the study is web-based integrated application which can help user control and monitor project's progress based on man hour and man power allocation and can be accessed from project site.
\end{abstract}

Keywords: man hour control, integrated application, web-based

\begin{abstract}
ABSTRAK
Tujuan dari penelitian ini adalah untuk menganalisis dan merancang aplikasi pengontrolan man hour yang terintegrasi, yaitu Manhour Integrated Control Application (MICA) pada perusahaan yang berbasis proyek. Aplikasi yang terintegrasi ini akan memudahkan user untuk memantau progress penggunaan man hour pada proyek dan kemudahaan akses dari lokasi site yang berbeda. Metodologi yang digunakan adalah (1) analisis pada proses bisnis yang berjalan dan mengidentifikasi kebutuhan user dengan melakukan wawancara, analisis dokumen terkait dan tinjauan pustaka, (2) perancangan sistem yang mencakup perancangan database dan rancangan user interface. Hasil yang ingin dicapai dalam penelitian ini adalah sebuah aplikasi terintegrasi yang berbasis web dimana sistem ini diharapkan dapat membantu organisasi dalam mengelola alokasi man hour dan man power proyek, memantau progres proyek berdasarkan pengunaan man hour dan memberikan kemudahan akses bagi user yang berada di lokasi proyek yang berbeda.
\end{abstract}

Kata kunci: pengontrolan manhour, aplikasi terintegrasi, web 


\section{PENDAHULUAN}

Tuntutan kebutuhan akan integrasi dan kemudahan akses terhadap sistem informasi kian meningkat seiring dengan perkembangan teknologi informasi. Integrasi sistem ini diperlukan untuk mengakomodir kebutuhan end-user dari berbagai level manajerial dan dari berbagai departemen yang berbeda. Kemudahan akses terhadap sistem informasi diperlukan untuk menjangkau end-user yang berada di lokasi yang berbeda dengan memanfaatkan teknologi jaringan maupun internet.

Pada perusahaan yang berbasis proyek, sistem pengelolaan man hour sangat diperlukan terkait kontrol yang harus dilakukan selama proyek berlangsung. Kontrol tersebut meliputi: kontrol terhadap alokasi sumber daya manusia, progress proyek dan kinerja proyek. PT XYZ sebuah perusahaan yang bergerak dalam bidang Engineering, Procurement dan Construction (EPC) merupakan perusahaan yang berbasis proyek. PT XYZ mengelola proyek-proyek EPC yang memungkinkan karyawan ditempatkan dilokasi proyek yang berbeda. Oleh karena itu dibutuhkan pengelolaan sumber daya manusia dan pengalokasian manhour yang efektif dan efisien.

Manhour Integrated Control Application (MICA) dapat membantu perusahaan berbasis proyek untuk mengelola sumber daya manusia dan mengontrol penggunaan man hour proyek secara lebih efektif dan efisien. Laporan yang dihasilkan dari aplikasi ini dapat memenuhi kebutuhan sampai ke level manajerial. MICA dibangun dengan menggunakan teknologi berbasis web, sehingga dapat di akses oleh karyawan yang berada di lokasi yang berbeda dengan menggunakan teknologi jaringan.

\section{METODE}

Penelitian ini dilakukan dengan beberapa tahapan: (1) studi pustaka; (2) analisis sistem yang meliputi analisis proses bisnis yang berjalan dan identifikasi kebutuhan informasi; (3) perancangan (Gambar 1) yang meliputi (1) perancangan database dan ERD, (2) perancangan user interface.

\section{Perancangan Basis Data}

Menurut Connoly \&Begg (2005, p. 291), perancangan basis data merupakan proses pembuatan suatu model sebuah basis data yang menggambarkan hubungan antara data yang dibutuhkan dalam pengembangan sebuah aplikasi yang akan mendukung operasional dan sasaran suatu perusahaan. Perancangan basis data dibagi dalam tiga tahapan yaitu: (1) conceptual database design, yaitu sSuatu proses pembentukan model dari informasi/entitas yang digunakan dalam perusahaan. Model data dibangun dengan menggunakan informasi spesifikasi kebutuhan user; (2) logical database design, yaitu proses pembentukan model dari informasi yang digunakan dalam perusahaan berdasarkan model data tertentu. Model data konseptual yang telah dibuat sebelumnya dipetakan dan diperbaiki ke dalam model data logika; (3) physical database design, yaitu proses yang menghasilkan deskripsi implementasi basis data pada penyimpanan sekunder. Menggambarkan struktur penyimpanan dan metode akses yang digunakan untuk mencapai akses yang efisien terhadap data.

\section{Rich Picture}

Rich Picture merupakan sebuah gambar yang dibuat berdasarkan hasil dari interview yang dilakukan terhadap user. Ideal nya interview tersebut dilakukan di tempat kerja user, sehingga kita dapat melakukan observasi apa yang mereka lakukan, produk apa yang mereka hasilkan dan dokumendokumen yang mendukung pekerjaan mereka, sehingga di dalam rich picture nanti dapat digambarkan 
semua informasi yang diberikan oleh user. Penggambaran Rich Picture merupakan proses iteratif dari pemahaman proses bisnis dan perbaikan terhadap pemahaman proses bisnis tersebut. Rich picture menggambarkan stakeholder utama, keterkaitan nya dan permasalahannya, sehingga penggambaran rich picture bersifat luas untuk menjelaskan permasalahan yang ada.

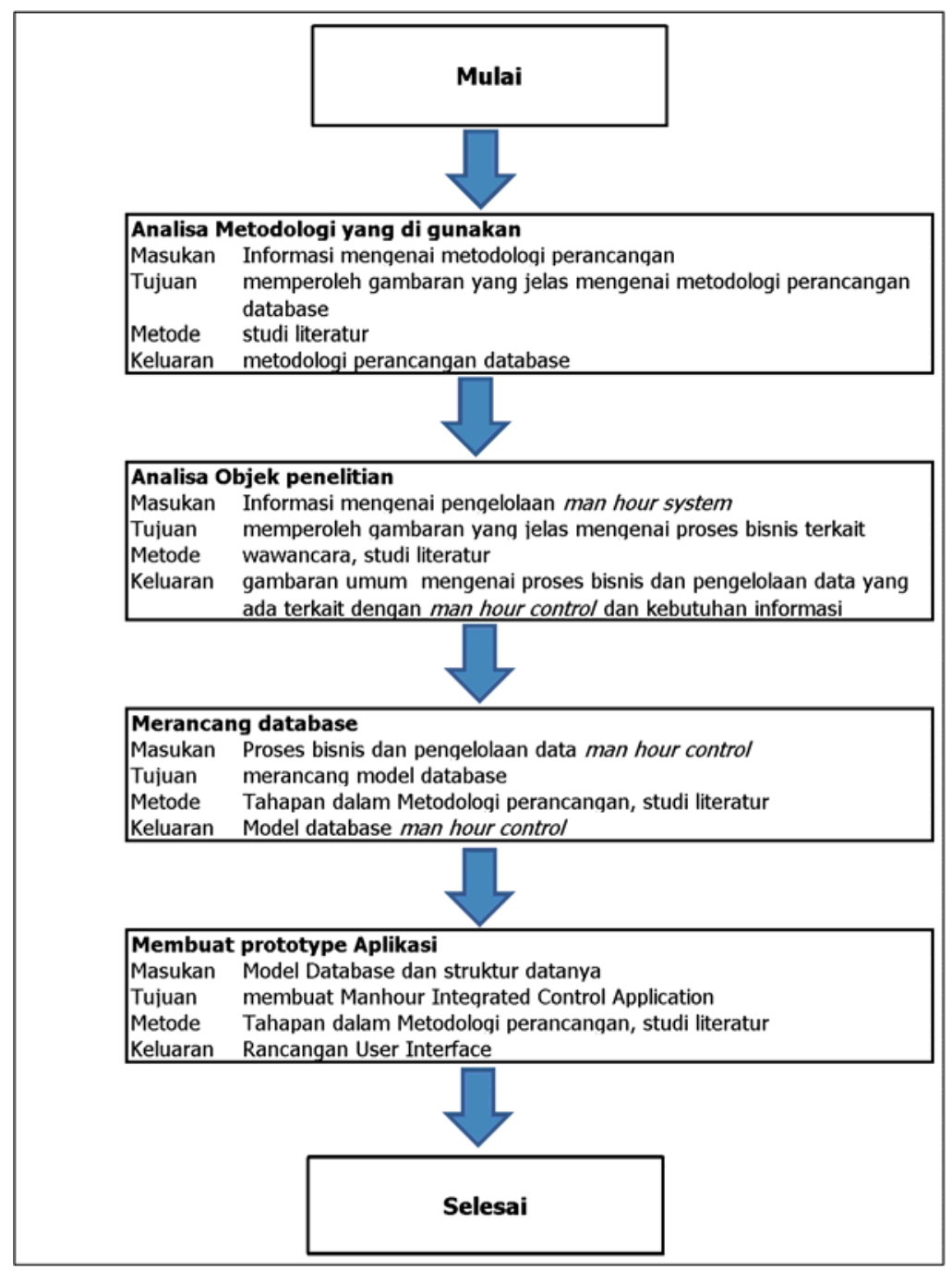

Gambar 1 Tahapan perancangan

\section{Use Case}

Menurut Bentley dan Whitten (2007:246) Use case adalah sebuah proses pemodelan fungsi dari sebuah sistem yang mengacu pada proses bisnis; siapa yang melakukan dan bagaimana sistem akan me-respon proses bisnis tersebut. Use case menggambarkan kebutuhan fungsional sistem dari eksternal user dan dengan cara yang mudah dipahami. Elemen dari use case berupa:

Use case: digambarkan dengan bentuk ellips untuk menggambarkan
aktifitas / proses bisnis




Actor: external user yang melakukan aktifitas dengan tujuan untuk
menyelesaikan suatu proses bisnis yang dapat menghasilkan nilai yang
terukur

\section{Extranet}

Menurut O’Brien dan Marakas (2009:223), extranet merupakan jaringan yang dikembangkan dengan memanfaatkan teknologi internet yang menghubungkan intranet perusahaan dengan customer, supplier atau rekan bisnis. Perusahaan dapat membangun direct private network atau membuat private, secure internet link yang di kenal dengan Virtual Private Network (VPN) atau perusahaan dapat juga menggunakan unsecured internet sebagai jaringan extranet dengan customer dan lain sebagainya dengan mengandalkan pada enkripsi data dan firewall untuk memberikan security yang baik.

\section{Perancangan User Interface}

Menurut O’Brien dan Marakas (2009:485), perancangan user interface (UI) bertujuan untuk membangun interaksi antara end-user dengan computer-based aplikasi. Perancangan UI merupakan suatu proses prototyping dimana model aplikasi dirancang dan dimodifikasi berdasarkan feedback dari end-user. Hasil dari rancangan UI berupa informasi yang spesifik mengenai rancangan layar, interaksi user dan komputer yang berupa form, report, audio respond dan lain-lain.

\section{HASIL DAN PEMBAHASAN}

\section{Analisis Proses Bisnis yang berjalan}

Berikut merupakan Rich Picture yang menggambarkan proses bisnis Man Hour Control System (MHCS) yang berjalan pada PT XYZ (Gambar 2). Aliran informasi dari karyawan masih bersifat manual (kartu absen, timesheet, leave dan overtime data masih dalam format hardcopy) sehingga baik HRD maupun MHCS staff harus menginputkan kembali data kedalam MHCS. Permasalahan yang terjadi adala:, (1) lamanya waktu peng-inputan data sehingga laporan yang dihasilkan juga mengalami keterlambatan; (2) terjadi kesalahan input atau data yang tidak ter-record; (3) data yang tidak ter-integrasi karena masing-masing bagian memiliki aplikasi tersendiri sehingga terjadi peng-inputan yang berulang-ulang.

\section{Analisis Kebutuhan Fitur}

PT XYZ memerlukan sebuah aplikasi manhour control yang berbasis web dengan pertimbangan kemudahan akses bagi karyawan yang berada di project site. Aplikasi ini akan dikembangkan dengan web-based dan memanfaatkan teknologi extranet, sehingga karyawan dapat mengakses aplikasi ini dari project site. Berikut adalah analisis kebutuhan fitur (Gambar 3) yang akan dikembangkan pada PT XYZ dengan nama Manhour Integrated Control Application (MICA).

\section{Analisis Sistem yang Diusulkan}

Berikut adalah rich picture (Gambar 4) yang menggambarkan sistem yang diusulkan dalam pengembangan MICA. 


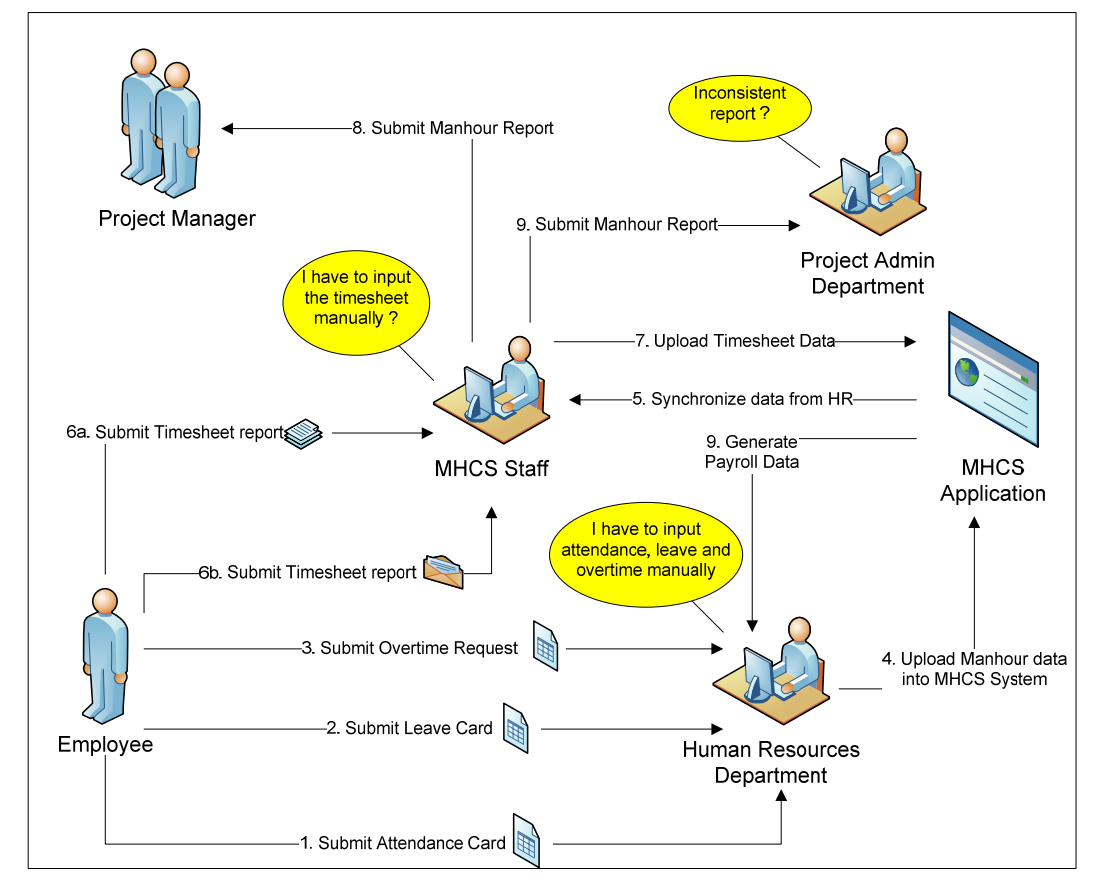

Gambar 2 Rich picture Man Hour Control Sistem pada PT XYZ
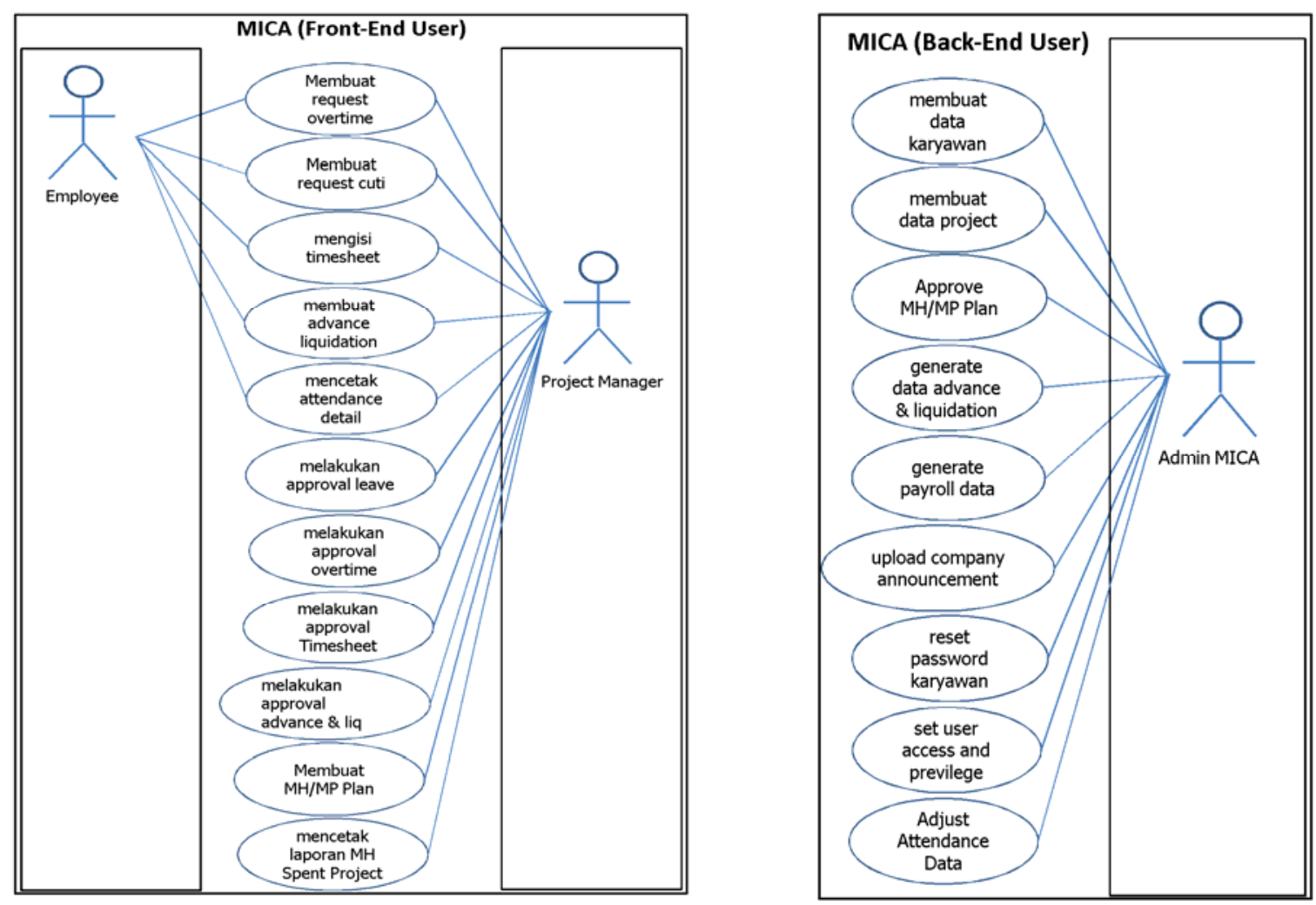

Gambar 3 Use case MICA 


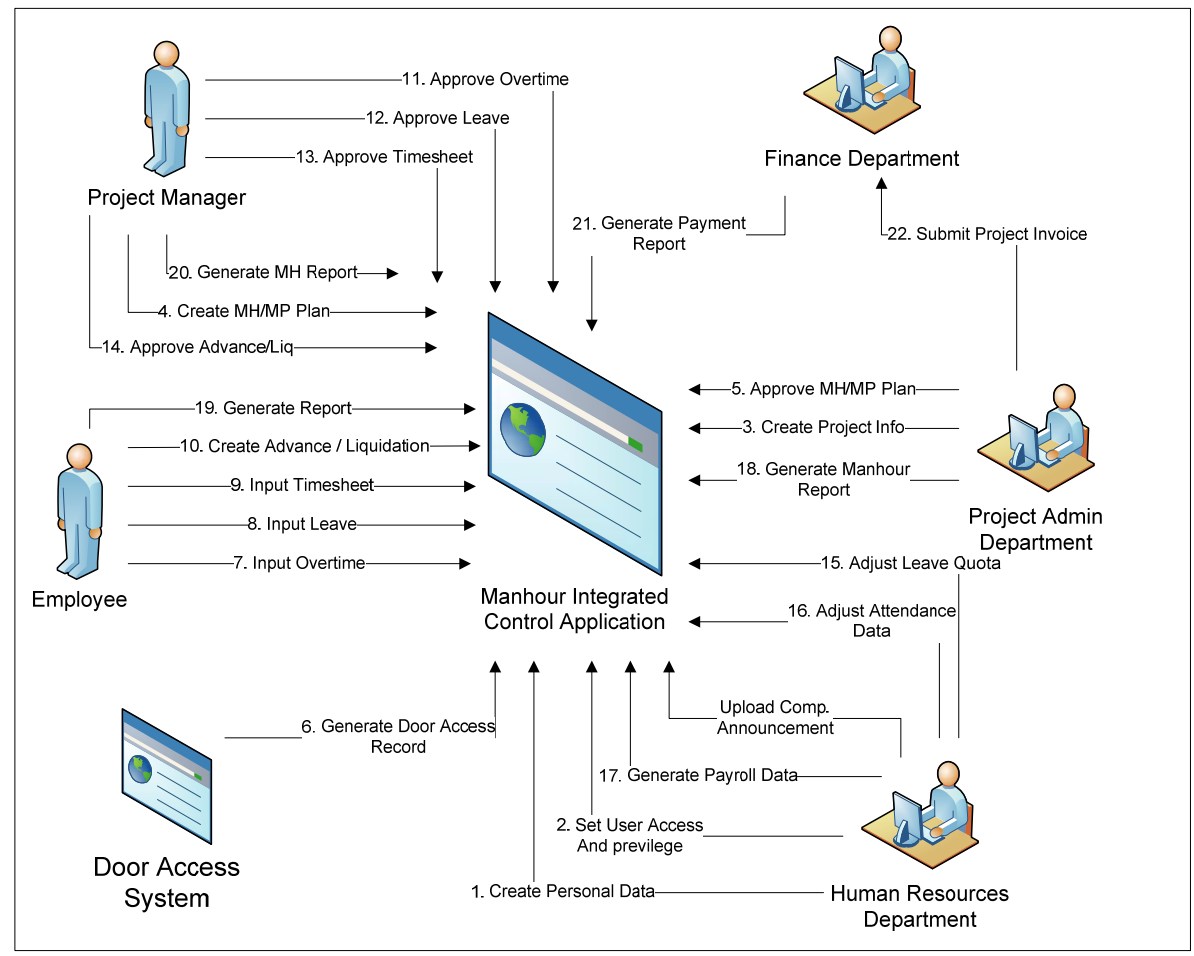

Gambar 4 Rich Picture Sistem yang diusulkan pada PT XYZ

Pengembangan aplikasi software ini terintegrasi dengan door access system yang secara otomatis dapat digunakan sebagai absensi karyawan yang berada di kantor pusat. Sehingga pencatatan absensi tidak perlu dilakukan secara manual lagi.

\section{Entity Relationship Diagram}

Berikut merupakan gambaran secara garis besar mengenai hubungan entitas yang terdapat pada pengembangan aplikasi MICA (Gambar 5).

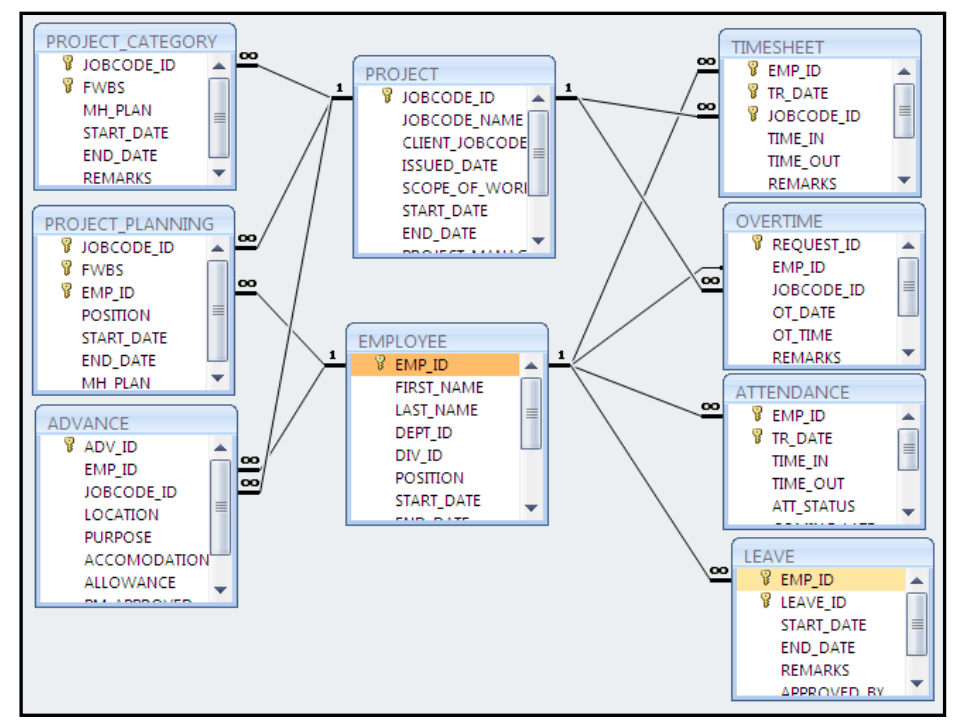

Gambar 5 Entity Relationship Diagram 


\section{Rancangan Layar}

Berikut beberapa rancangan layar pada aplikasi MICA (Gambar 6 - 18).

\section{PENUTUP}

Berdasarkan hasil penelitian yang dilakukan dapat disimpulkan bahwa aplikasi Man Hour Integrated Aplication (MICA) yang memanfaatkan teknologi intranet ini dapat membantu meningkatkan kinerja perusahaan dalam pengelolaan data yang terkait dengan kontrol man hour dan man power dan dapat menjangkau akses user yang berada di lokasi proyek. Dengan adanya integrasi data dalam aplikasi MICA tersebut tentunya akan meminimalisir kesalahan akibat human error, input yang dilakukan secara berulang-ulang dan penyajian informasi dapat terlaksana secara real time.

\section{DAFTAR PUSTAKA}

Bentley, Lonnie D. \& Whitten, Jeffrey L. (2007). System Analysis and Design for Global Enterprise ( $7^{\text {th }}$ edition). New York: McGraw-Hill.

Connoly, T. M., \& Begg, C. E. (2005). Database System: a Practical Approach to Design, Implementation, and Management (5th ed.). Harlow: Pearson Education Limited.

O’Brien, James \& Marakas, George M.. (2009). Management Information System ( ${ }^{\text {th }}$ edition). New York: McGraw-Hill.

\section{APPENDIX}

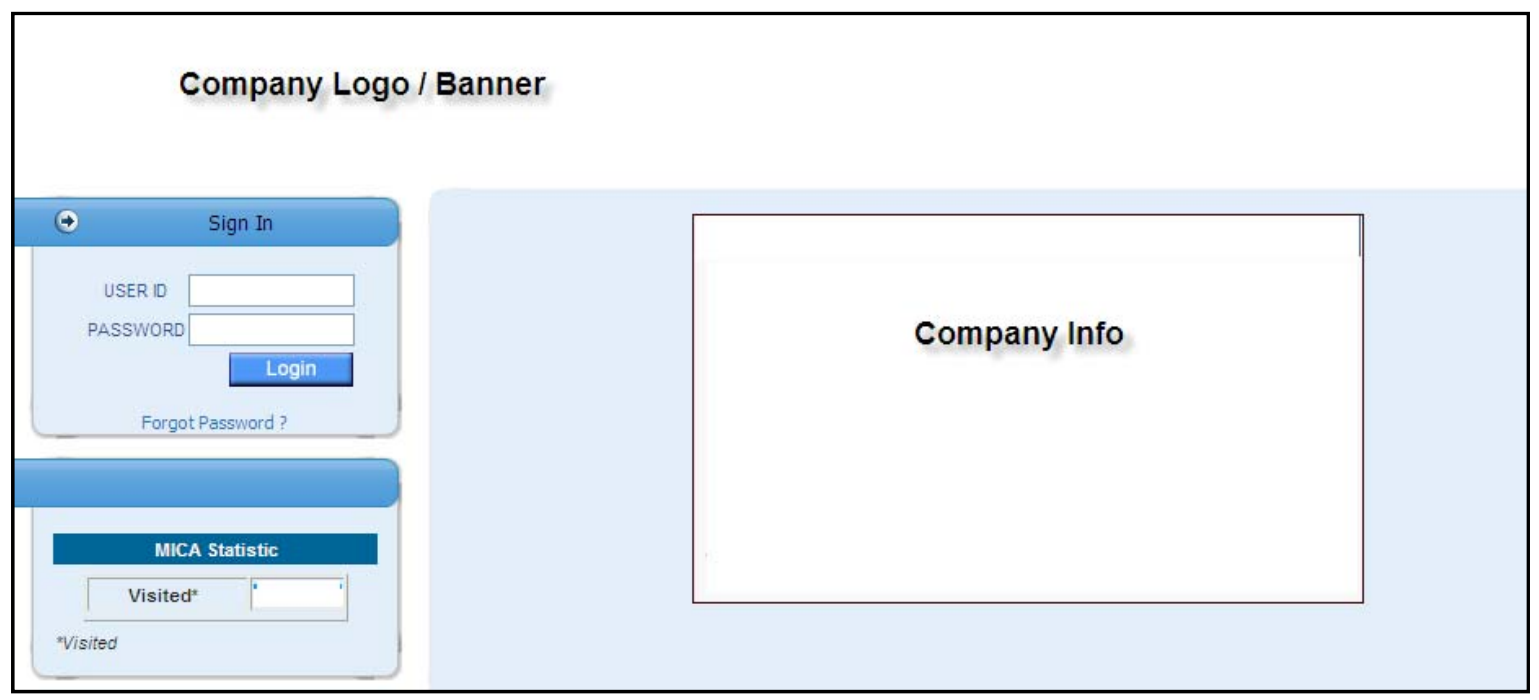

Gambar 6 Rancangan layar Login 


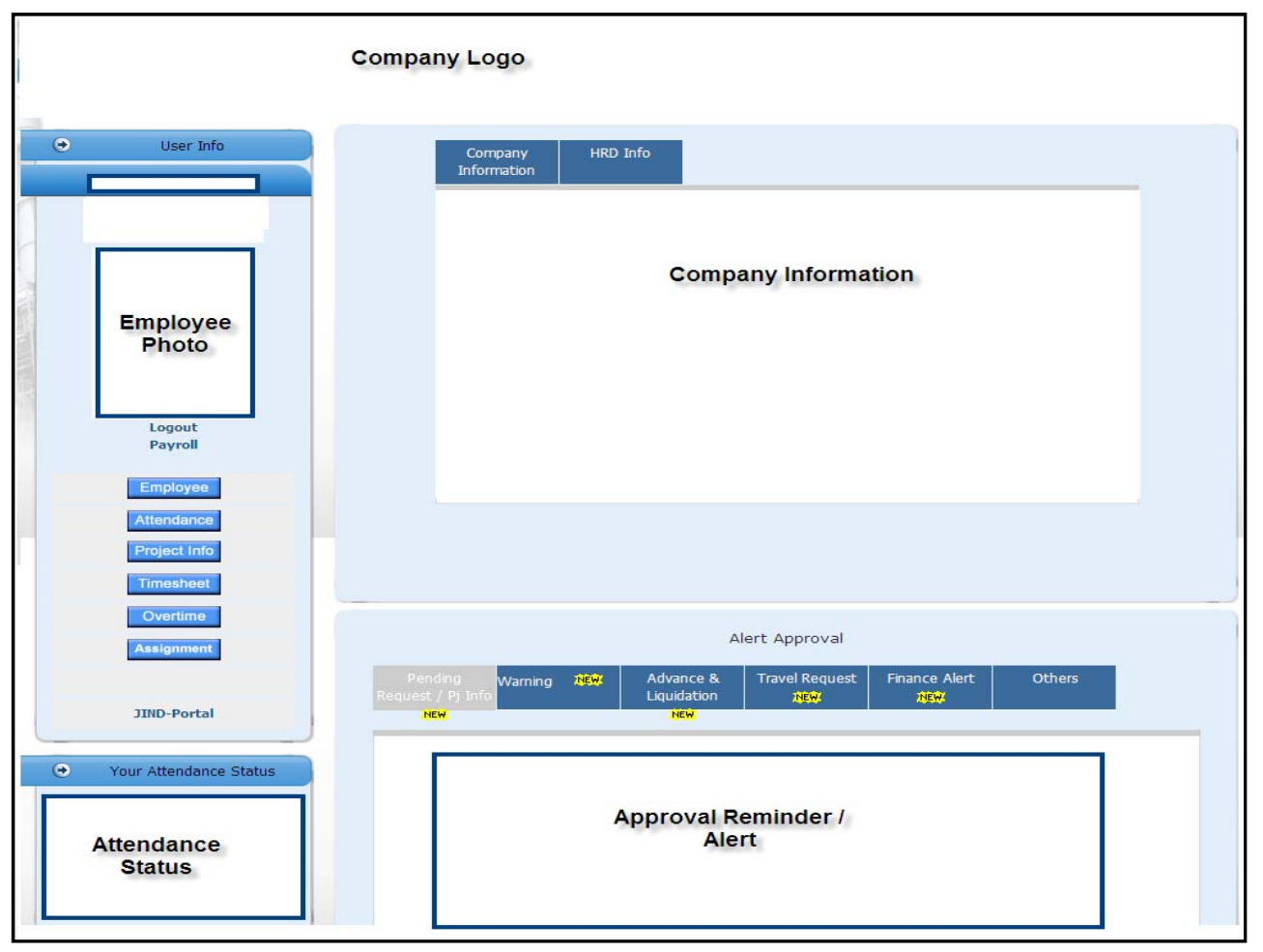

Gambar 7 Rancangan layar Home

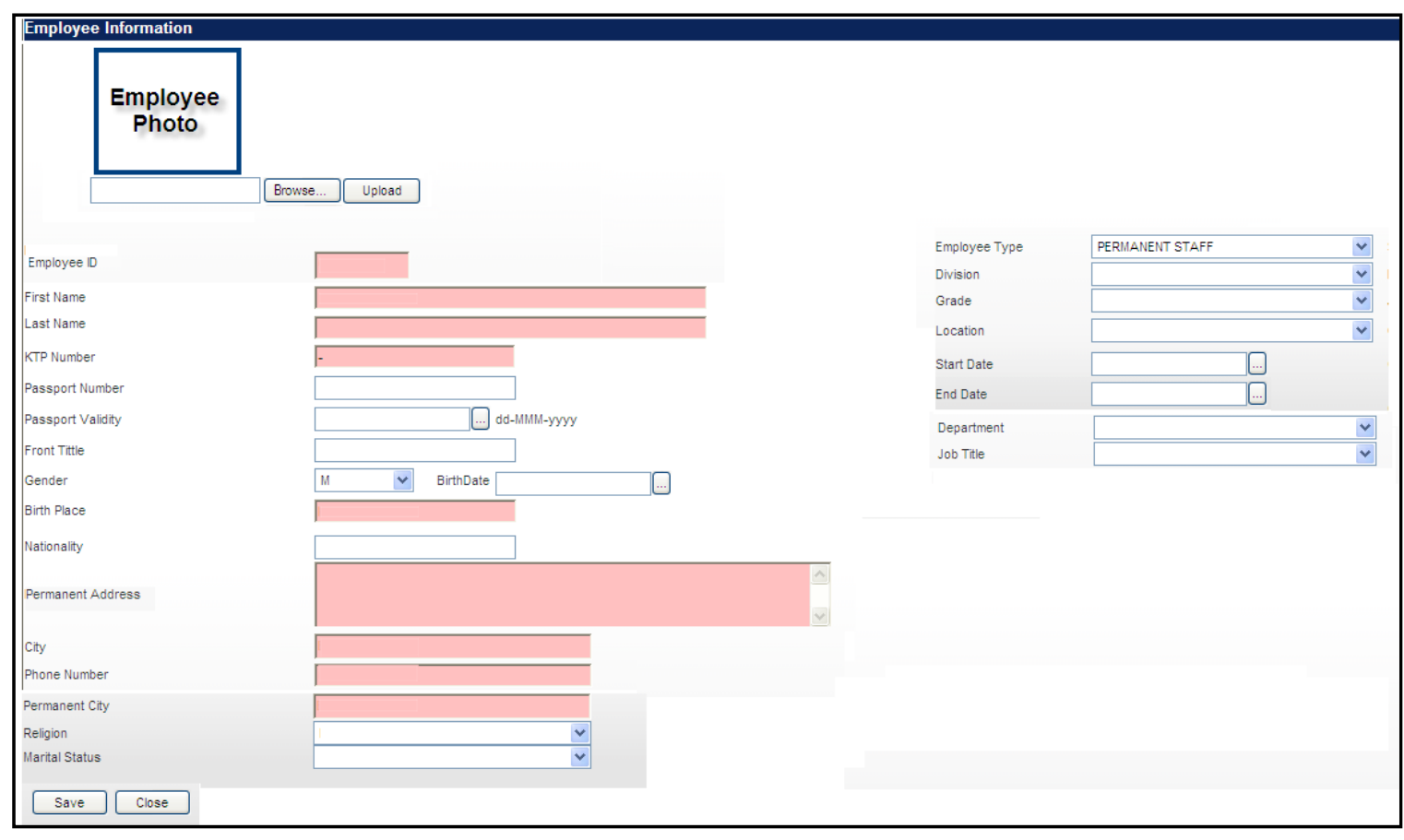

Gambar 8 Rancangan layar Personal Data Entry 


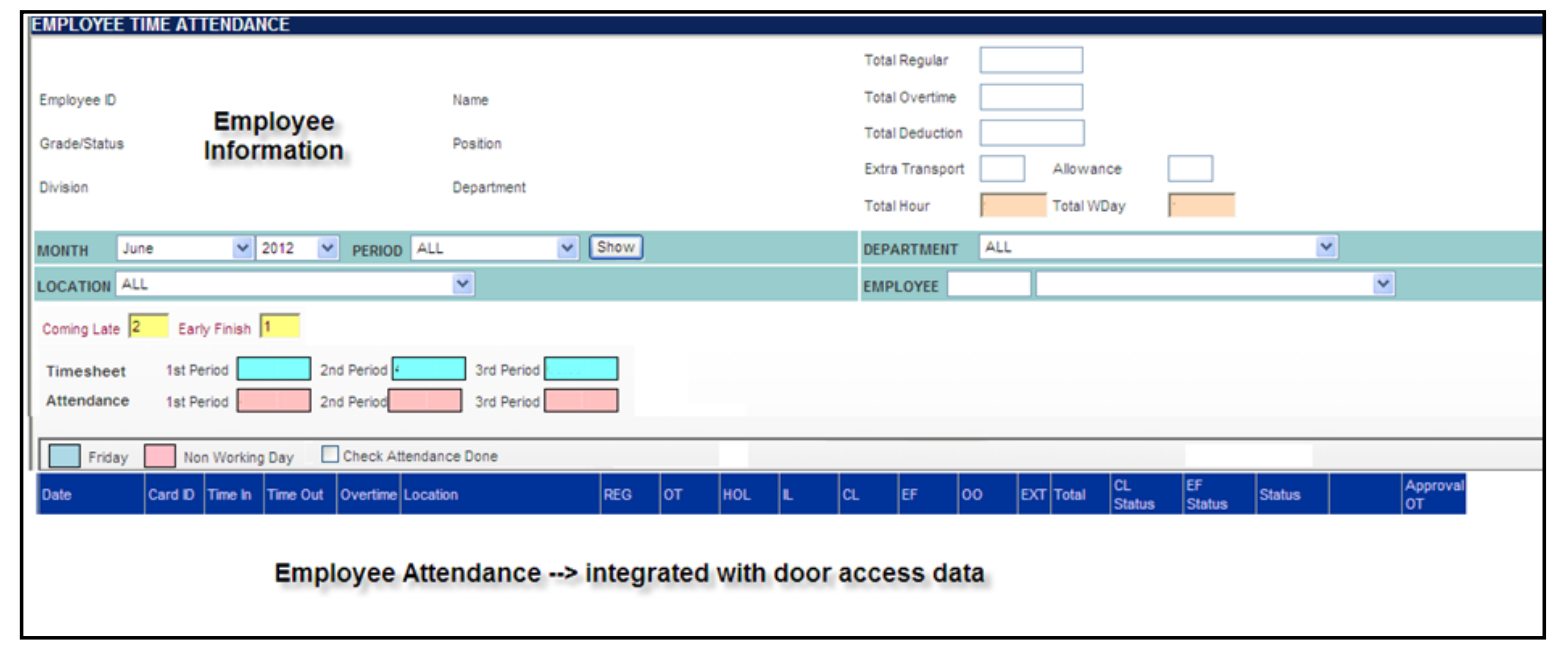

Gambar 9 Rancangan layar Employee Attendance

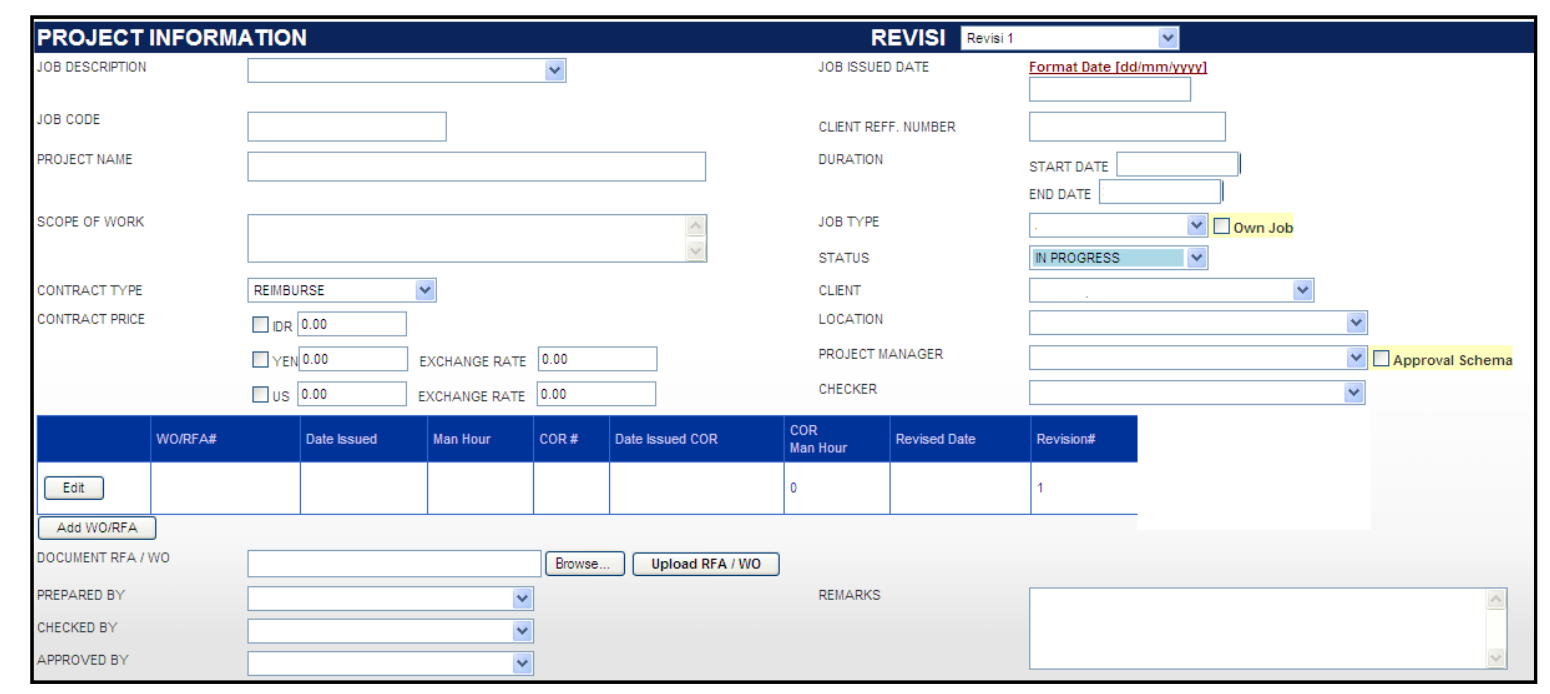

Gambar 10 Rancangan layar Create Project

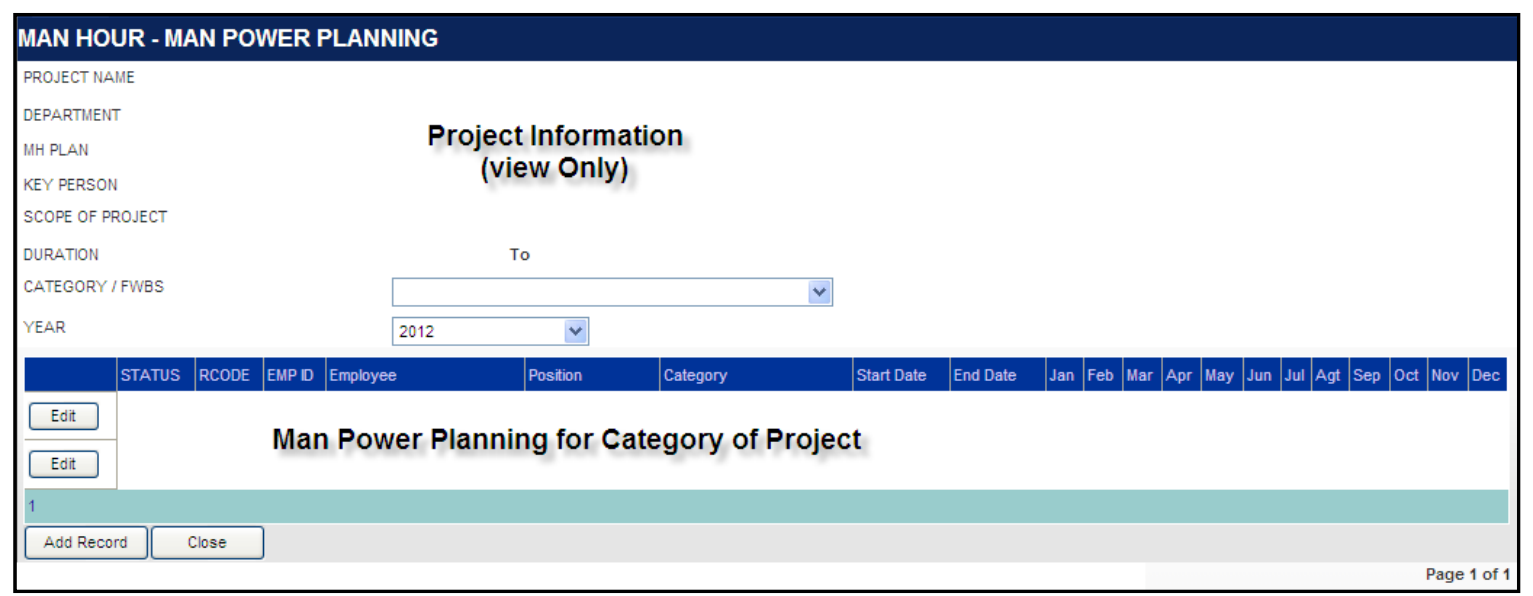

Gambar 11 Rancangan layar Create MH/MP Plan 


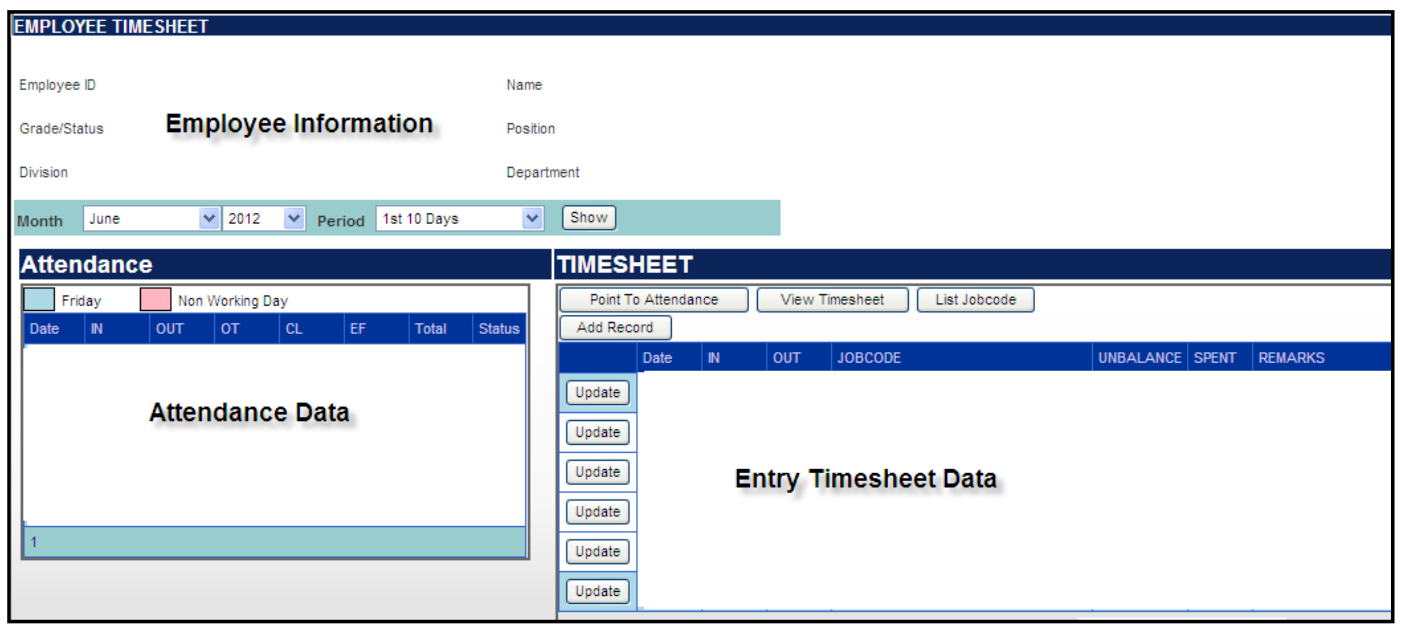

Gambar 12 Rancangan layar Input Timesheet

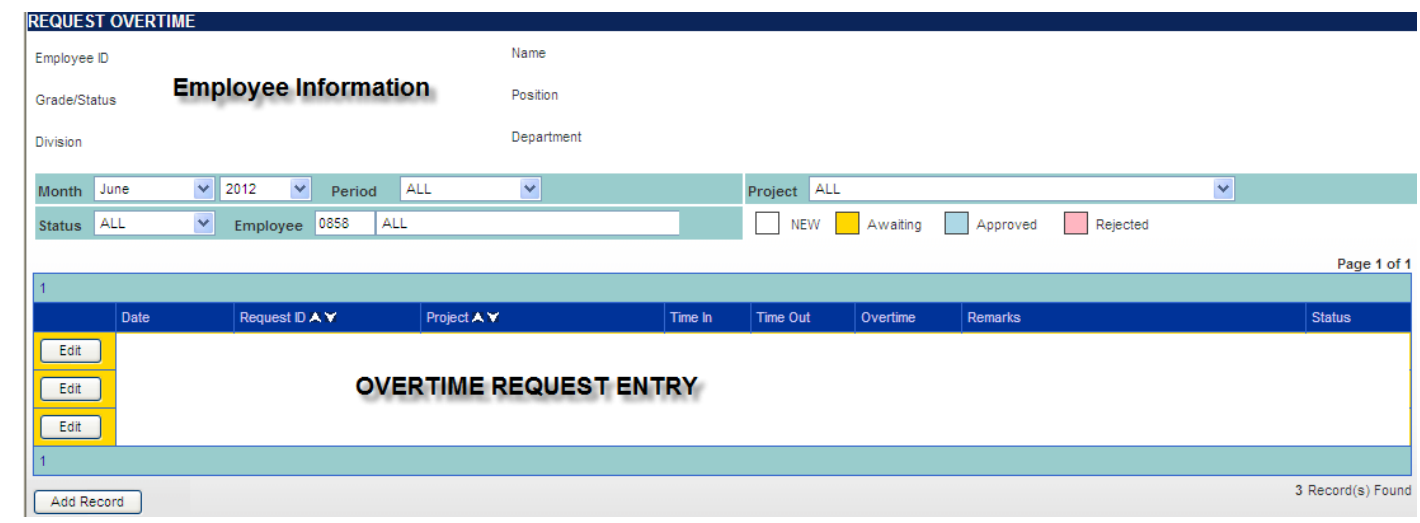

Gambar 13 Rancangan layar Request Overtime

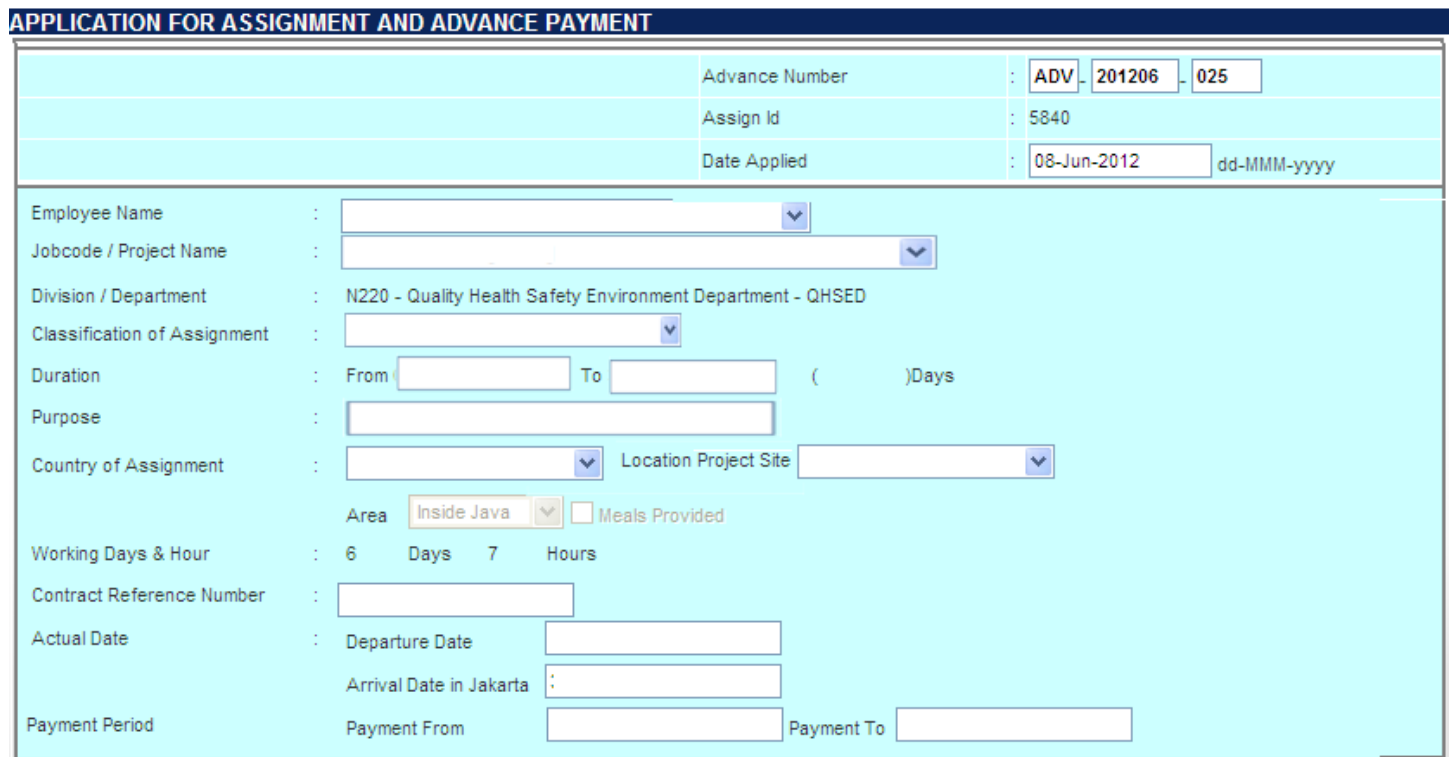

Gambar 14 Rancangan layar Create Advance \& Liquidation 


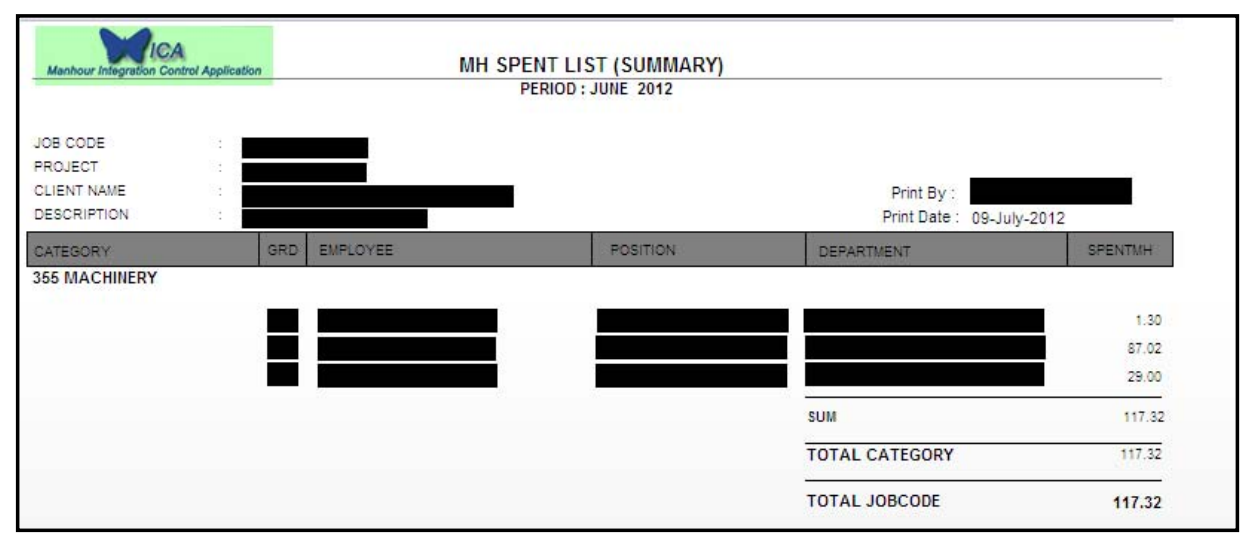

Gambar 15 Rancangan layar Output MH Spent List

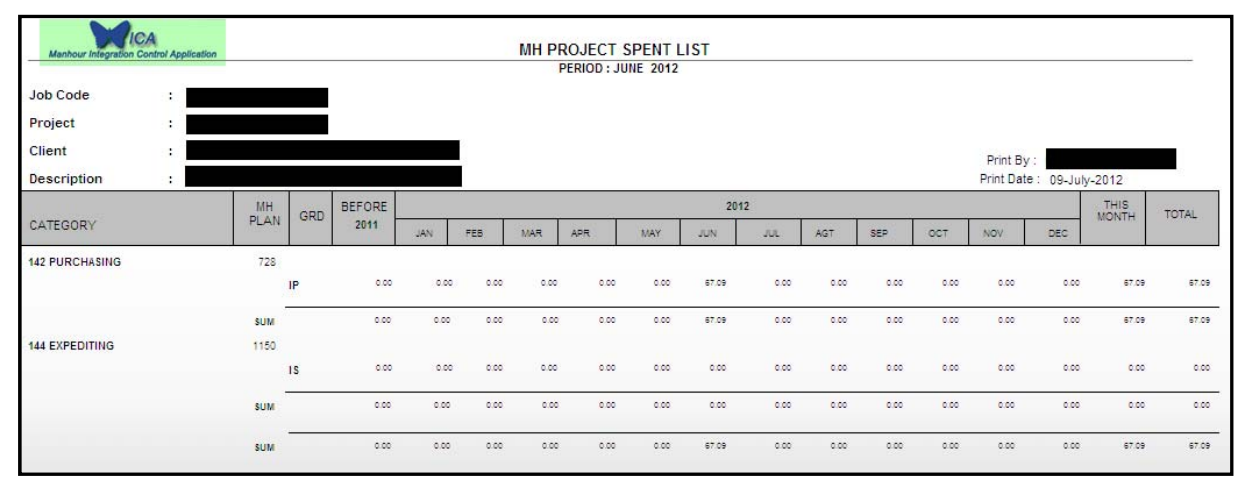

Gambar 16 Rancangan layar Output MH Spent Project

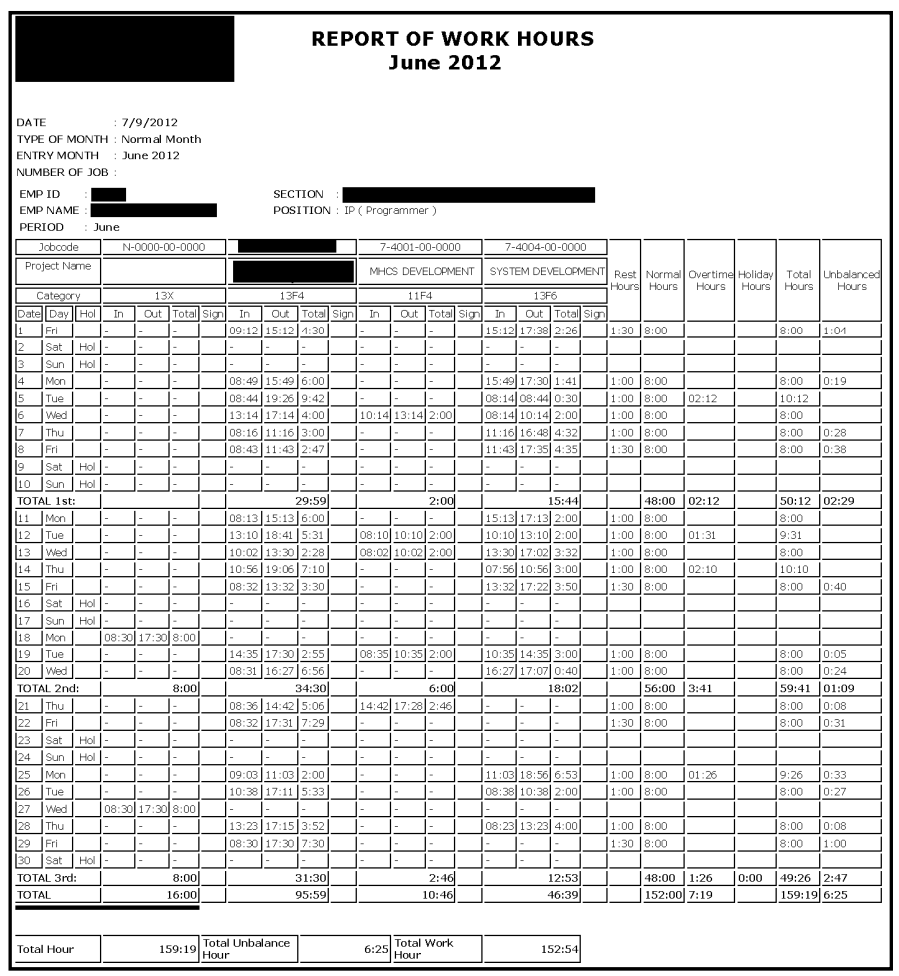

Gambar 17 Rancangan layar Output Timesheet 


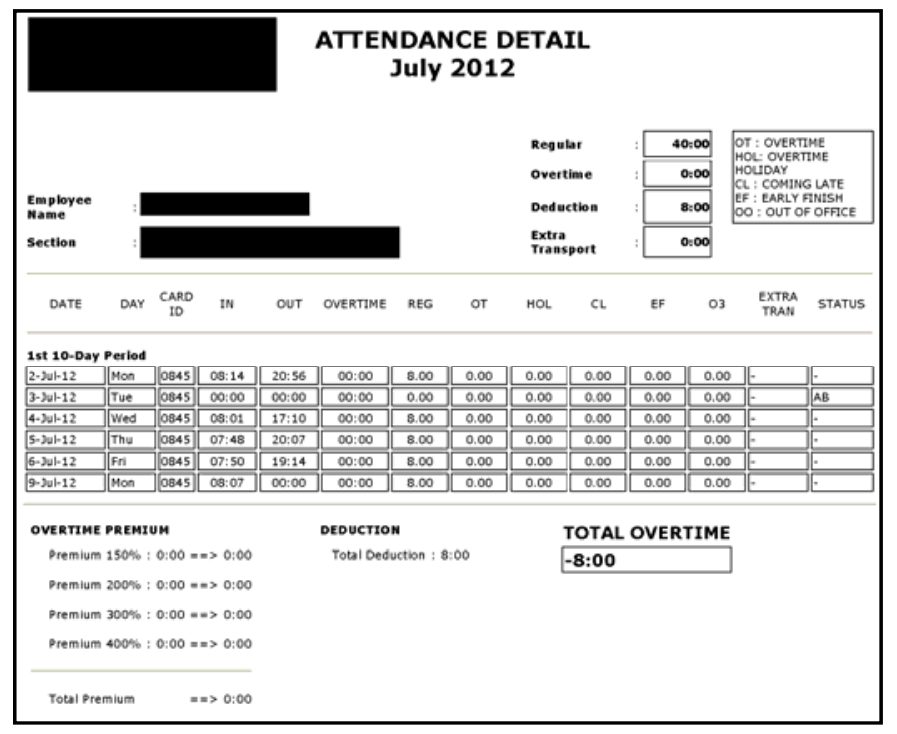

Gambar 18 Rancangan layar Output Attendance Detail 